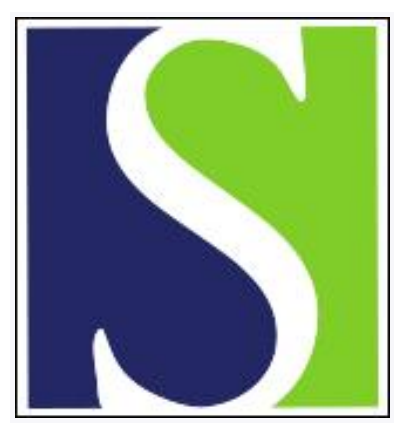

Scand J Work Environ Health 1986;12(1):27-31

https://doi.org/10.5271/sjweh.2177

Issue date: Feb 1986

Oral cavity and laryngeal cancers among man-made mineral fiber production workers.

by Moulin JJ, Mur JM, Wild P, Perreaux JP, Pham QT

This article in PubMed: www.ncbi.nlm.nih.gov/pubmed/3961439

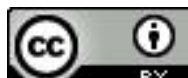




\title{
Oral cavity and laryngeal cancers among man-made mineral fiber production workers
}

\author{
by Jean J Moulin, MD, ${ }^{1}$ Jean M Mur, MD, ${ }^{1}$ Pascal Wild, PhD, ${ }^{1}$ Jean P Perreaux, MD, ${ }^{2}$ \\ Quang T Pham, MD
}

\begin{abstract}
MOULIN JJ, MUR JM, WILD P, PERREAUX JP, PHAM QT. Oral cavity and laryngeal cancers among man-made mineral fiber production workers. Scand $J$ Work Environ Health 12 (1986) 27-31. From 1975 to 1984, the incidence of cancer was determined among workers employed in a French man-made mineral fiber (MMMF) production plant. The cohort, including 1374 fully active or retired men, represented 12793 person-years. Forty-one patients had cancer, 19 of which were in the upper respiratory and alimentary tract and five of which were lung cancers. The number of lung cancers observed did not significantly differ from that expected [standardized incidence ratio (SIR) 0.7]. However the incidence of upper respiratory and alimentary tract cancers was significantly higher (SIR 2.2), especially for those in the larynx (SIR = 2.3), pharynx (SIR 1.4), and buccal cavity (SIR 3.0). The relative risk of cancers in the upper respiratory and alimentary tracts seemed to increase with the length of exposure to glass fibers and exceeded the value of 3.0 for more than 10 years of exposure. This result does not seem to be attributable to an excess of tobacco and/or alcohol consumption. No previous survey of the MMMF industry has shown such a risk, except in Italy. Thus this finding has to be confirmed.
\end{abstract}

Key terms: cancer incidence, occupational epidemiology.

Man-made mineral fibers (MMMF) have recently become more extensively used. They are used for thermal and acoustic insulation, in the textile industry, and for the reinforcing of plastic material. Although the chemicophysical properties of these fibers make them different from asbestos, their carcinogenicity must be considered. MMMF intrapleural inoculation in experimental models has produced cancers $(22,23,25)$.

Several epidemiologic surveys have been conducted in Europe and in North America (1, 2, 4, 5, 6, 7, 9, 10, $13,14,18,21)$. They were aimed at investigating an excess of cancer incidence among populations working in the MMMF industry. Probably because of the analogy with asbestos, these surveys were mainly focused on malignant tumors of the lung which, furthermore, are the first cause of mortality from cancer in the male population of industrialized countries.

In France, where seven MMMF factories are established, no epidemiologic survey has been conducted until now, probably because of the difficulties in the follow-up due to confidentiality constraints. In the present paper we report the results of a historical prospective study of cancer incidence. The study was conducted in a factory where an industrial physician had noticed an excess of cancers in the upper respiratory and alimentary tracts, ie, cancers in the pharynx, larynx, and buccal cavity.

\footnotetext{
1 National Institute for Research in Safety and Occupational Health, Department of Epidemiology, Vandoeuvre, France.

2 Occupational physician.

3 National Institute for Health and Medical Research, U 14, Respiratory Physiopathology, Vandoeuvre, Fränce.
}

Reprint requests to: Dr JJ Moulin, INRS, Avenue de Bourgogne, BP 27, F-54501 Vandoeuvre cedex, France.

\section{Subjects and methods}

The factory, located in the north of France, produces glasswool used mainly for thermal insulation in the building industry, shipyards, and car manufacturing and for the production of household appliances. The first production lines started in 1940 and are still in operation. Annual production was $5000 \mathrm{t}$ in 1950 , $15000 \mathrm{t}$ in 1960 , and $50000 \mathrm{t}$ in 1980 . The manufacturing processes generate discontinuous fibers coated with a thermosetting binder essentially made of water, phenol, formol, ammonia, urea, and oil. The mean diameter of the fibers produced by the factory is $6.4 \mu \mathrm{m}, 30 \%$ have diameters $<3 \mu \mathrm{m}$, and $10 \%$ are $<1 \mu \mathrm{m}$.

The cohort under study consists of all male workers present at the factory between 1 January 1975 and 31 December 1984 who had been working for at least one full year. Person-years, including those of active and retired workers, were computed from this period. The members of the cohort lost to follow-up (101 persons, 465 person-years) were considered still living and thus still contributed to the person-years. The total size of the cohort was 1374 men, of whom $96 \%$ were French. Their occupational history in the factory since the date of entry was reconstituted. The cases of cancers in this cohort were identified from the social insurance records of the company. The coverage is unknown but probably very good. Diagnoses were ascertained by histological reports, hospital records, or from attending physician's reports. Tobacco consumption was estimated on the basis of information from the subjects still present in the factory in 1983 (966 men). No data concerning alcohol consumption could be obtained. 
Environmental surveys were performed in 1981 in order to measure the pollution by fibers. For these surveys, occupational groups were identified according to place of work, and workers were asked to wear sampling equipment during their workshift. In order to calculate the standardized incidence ratio (SIR) for cancers, we estimated the expected numbers of cancers, for five-year age groups and for the whole period, by using data from three regional cancer registers existing in France $(8,19,20)$. These data were found to be homogeneous. Moreover, using the incidence/ mortality ratio, we estimated the case coverage to be above $95 \%$. Thus the calculated standardized incidence ratios are probably accurate. The criteria for diagnosis were the same as in the cohort. The reference incidence rates, for each age group, were determined as the average rates in the three registers, weighted according to the population size concerned with each register. The registers concerned the period between 1975 and 1981 but did not include the population of the region where the factory was established. In order to verify that this reference (the only one we could use) was not too incorrect, we checked that mortality rates by cancer, in the region where the plant is located, did not differ markedly from those of regions having registers. For the standardized incidence ratios $95 \%$ confidence intervals were computed on the basis of the Poisson distribution.

\section{Results}

In 1984 the mean age of the cohort was 44.4 (SD 11.3) years, the mean length of employment being 16.6 (SD 8.8) years. Table 1 shows the age distribution of the person-years.
The results of the inquiry about tobacco consumption are given in table 2. For the whole cohort, they do not differ from values obtained from a poll of the French male population of the same age in 1979. There was no difference in tobacco consumption, inside the factory, according to occupation. The two environmental surveys showed low fiber concentrations, the average respirable fiber concentrations being below 0.2 fibers $/ \mathrm{cm}^{3}$. More detailed values have been given elsewhere (12).

During the 10 years of survey, 41 subjects were affected by cancer, 19 cases of which occurred in the upper respiratory or alimentary tract (table 3 ). Three patients had a cancer in two locations (soft palate + tongue, tonsil + hypopharynx, and laryn $x+$ tonsil). Precise histologies were determined by hospital departments but were reported for only six cases (squamouscelled carcinomas). The comparison with the statistics of the incidence registers (table 4) showed a significant excess for cancer in the upper respiratory and alimentary tracts (SIR 2.18, p < 0.01), whereas there was no significant difference for lung cancers (SIR 0.74) and other malignant tumors (SIR 0.77). An increased incidence of laryngeal cancers (observed 5, SIR 2.30) as pharyngeal (observed 5, SIR 1.40) and oral cavity cancers (observed 9, SIR 3.01) was observed. The mean time since first exposure was 17.6 years.

The cohort was divided into the administrative staff, the maintenance staff, and the production workforce. The last category was divided according to work duration in workplaces contaminated by fibers (production, storage, handling, manufacture). Upper respiratory and alimentary tract cancers were not in excess among the administration and maintenance workers. On the contrary, they were in excess among workers exposed to glass fibers, and this excess was

Table 1. Person-years by age group and by time since first employment.

\begin{tabular}{|c|c|c|c|c|c|c|c|}
\hline \multirow{2}{*}{$\begin{array}{l}\text { Time since first } \\
\text { employment }\end{array}$} & \multicolumn{6}{|c|}{ Age group (years) } & \multirow{2}{*}{ Total } \\
\hline & $15-24$ & $25-34$ & $35-44$ & $45-54$ & $55-64$ & $65-74$ & \\
\hline $\begin{array}{l}1-9 \text { years } \\
10-19 \text { years } \\
\geq 20 \text { years }\end{array}$ & $\begin{array}{l}740 \\
-\end{array}$ & $\begin{array}{r}2737 \\
847 \\
1\end{array}$ & $\begin{array}{r}1102 \\
2054 \\
565\end{array}$ & $\begin{array}{r}453 \\
1184 \\
1542\end{array}$ & $\begin{array}{r}59 \\
350 \\
880\end{array}$ & $\begin{array}{r}5 \\
84 \\
190\end{array}$ & $\begin{array}{l}5096 \\
4519 \\
3178\end{array}$ \\
\hline Total & 740 & 3585 & 3721 & 3179 & 1289 & 279 & 12793 \\
\hline
\end{tabular}

Table 2. Tobacco consumption in different groups of employees and in France.

\begin{tabular}{|c|c|c|c|c|c|c|c|}
\hline \multirow{3}{*}{ Group } & \multicolumn{5}{|c|}{ Cigarette smoking category } & \multirow{3}{*}{$\begin{array}{l}\text { Current } \\
\text { pipe or } \\
\text { cigar } \\
\text { smokers } \\
(\%)\end{array}$} & \multirow{3}{*}{ Number } \\
\hline & \multirow{2}{*}{$\begin{array}{c}\text { Never } \\
\text { smokers } \\
(\%)\end{array}$} & \multirow{2}{*}{$\begin{array}{c}\text { Ex- } \\
\text { smokers } \\
(\%)\end{array}$} & \multicolumn{3}{|c|}{ Current smokers } & & \\
\hline & & & $\begin{array}{c}1-10 / \mathrm{d} \\
(\%)\end{array}$ & $\begin{array}{c}11-20 / d \\
(\%)\end{array}$ & $\begin{array}{c}>20 / \mathrm{d} \\
(\%)\end{array}$ & & \\
\hline \multirow{2}{*}{$\begin{array}{l}\text { Nonmanual workers } \\
\text { Nonexposed manual workers } \\
\text { Exposed manual workers } \\
\text { France (poll of men between } \\
18-64 \text { years of age, 1979) }\end{array}$} & $\begin{array}{l}27.1 \\
23.6 \\
23.6\end{array}$ & $\begin{array}{l}32.8 \\
23.1 \\
28.1\end{array}$ & $\begin{array}{r}7.4 \\
10.0 \\
11.5\end{array}$ & $\begin{array}{l}25.4 \\
33.7 \\
27.5\end{array}$ & $\begin{array}{l}5.7 \\
8.6 \\
7.9\end{array}$ & $\begin{array}{l}1.6 \\
1.0 \\
1.4\end{array}$ & $\begin{array}{l}122 \\
208 \\
636\end{array}$ \\
\hline & \multicolumn{2}{|c|}{$43.2^{\mathrm{a}}$} & 18.5 & 25.0 & 10.2 & 3.1 & 384 \\
\hline
\end{tabular}

a Never smokers and exsmokers combined. 
significant in the stratum of workers exposed for more than 10 years. Moreover, a relationship between the duration of exposure and the standardized incidence ratio for upper respiratory and alimentary tract cancers seemed to appear, but could not be statistically confirmed. For lung cancers, as well as for other cancers, the standardized incidence ratios did not depend on the type of occupation or duration of exposure to fibers (table 4).

\section{Discussion}

This survey, conducted in France, provides two main results. First, it does not reveal any excess in lung cancers among workers exposed to MMMF. According to a recent literature review published by Saracci \& Simonato (17), four surveys did not indicate any excess in lung cancers, whereas five others did. However, in those five surveys, the excess in lung cancers had no significant relationship with fabrication processes or with the duration or intensity of exposure. Second, a significant excess of cancers in the upper respiratory and alimentary tracts was found, and the incidence seems to be correlated with the duration of exposure. This excess may be underestimated due to the fact that the vital status (and medical history) was unknown for 101 subjects lost to follow-up. As far as we know, this observation has not yet been mentioned in the litera- ture. In table 5, which summarizes information published in Europe and North America, no such risk can be observed, except for Italy. In this country, Bertaz-

Table 3. Number of observed cases of cancer.

\begin{tabular}{|c|c|c|}
\hline $\begin{array}{l}\text { ICDa } \\
\text { (8 } 8^{\text {th }} \text { revision) }\end{array}$ & Site & Number \\
\hline & Buccal cavity & \\
\hline 140 & Lip & 1 \\
\hline 141 & Tongue & 2 \\
\hline 144 & Floor of mouth & 4 \\
\hline \multirow[t]{3}{*}{145} & Soft palate & 1 \\
\hline & Tongue + soft palate & 1 \\
\hline & Pharynx & \\
\hline 146 & Oropharynx & 2 \\
\hline 148 & Hypopharynx & 2 \\
\hline & Tonsil + hypopharynx & 1 \\
\hline \multirow[t]{3}{*}{161} & Larynx & \\
\hline & Larynx & 4 \\
\hline & Larynx + tonsil & 1 \\
\hline 150 & Esophagus & 1 \\
\hline $151-158$ & Digestive system & 7 \\
\hline 162 & Bronchus and lung & 5 \\
\hline 170 & Bone & 1 \\
\hline 185 & Prostate & 2 \\
\hline 189 & Kidney & 1 \\
\hline 191 & Central nervous system & 1 \\
\hline 200 & Malignant Iymphoma & 2 \\
\hline 203 & Multiple myeloma & 2 \\
\hline $140-208$ & All neoplasms & 41 \\
\hline
\end{tabular}

a $I C D=$ International Classification of Diseases.

Table 4. Cancer incidence analysis by site and by duration of exposure. (ICD = International Classification of Diseases, SIR = standardized incidence ratio, $95 \% \mathrm{Cl}=95 \%$ confidence intervals)

\begin{tabular}{|c|c|c|c|c|c|c|c|c|c|c|}
\hline \multirow[t]{2}{*}{ Group } & \multirow[t]{2}{*}{ Person-years } & \multicolumn{3}{|c|}{$\begin{array}{l}\text { Upper respiratory and } \\
\text { alimentary tract cancers } \\
\text { (ICD } 140-149,161)\end{array}$} & \multicolumn{3}{|c|}{ Lung cancer (ICD 162) } & \multicolumn{3}{|c|}{ Other cancers } \\
\hline & & Observ & SIR & $95 \% \mathrm{Cl}$ & Obsen & SIR & $95 \% \mathrm{Cl}$ & Observ & SIR & $95 \% \mathrm{Cl}$ \\
\hline $\begin{array}{l}\text { Administration } \\
\text { Maintenance } \\
\text { Production } \\
\text { workforce }\end{array}$ & $\begin{array}{r}881 \\
2088\end{array}$ & - & $\begin{array}{l}0.00 \\
0.71\end{array}$ & $\begin{array}{l}0.00-4.61 \\
0.02-3.98\end{array}$ & $\begin{array}{r}1 \\
-\end{array}$ & $\begin{array}{l}1.43 \\
0.00\end{array}$ & $\begin{array}{l}0.04-7.96 \\
0.00-3.07\end{array}$ & $\begin{array}{l}2 \\
1\end{array}$ & $\begin{array}{l}0.95 \\
0.27\end{array}$ & $\begin{array}{l}0.12-3.44 \\
0.01-1.51\end{array}$ \\
\hline $\begin{array}{l}\text { Nonexposed } \\
1-9 \text { years } \\
10-19 \text { years } \\
\geq 20 \text { years }\end{array}$ & $\begin{array}{l}1206 \\
4434 \\
2771 \\
1413\end{array}$ & $\begin{array}{l}1 \\
3 \\
7 \\
7\end{array}$ & $\begin{array}{l}1.67 \\
2.02 \\
3.04 \\
3.33\end{array}$ & $\begin{array}{l}0.04-9.29 \\
0.41-5.84 \\
1.22-6.27 \\
1.34-6.87\end{array}$ & $\begin{array}{l}- \\
2 \\
1 \\
1\end{array}$ & $\begin{array}{l}0.00 \\
1.82 \\
0.63 \\
0.56\end{array}$ & $\begin{array}{l}0.00-9.22 \\
0.22-6.57 \\
0.02-3.48 \\
0.01-3.10\end{array}$ & $\begin{array}{l}1 \\
4 \\
5 \\
4\end{array}$ & $\begin{array}{l}0.59 \\
1.08 \\
0.94 \\
0.73\end{array}$ & $\begin{array}{l}0.01-3.28 \\
0.29-2.77 \\
0.31-2.20 \\
0.20-1.86\end{array}$ \\
\hline Total & 12793 & 19 & 2.18 & $1.31-3.41$ & 5 & 0.74 & $0.24-1.72$ & 17 & 0.77 & $0.45-1.24$ \\
\hline
\end{tabular}

Table 5. Data from studies of male workers producing man-made vitreous fibers.

\begin{tabular}{|c|c|c|c|c|c|}
\hline \multirow[t]{2}{*}{ Study } & \multirow{2}{*}{ Person-years } & \multicolumn{2}{|c|}{$\begin{array}{l}\text { Buccal cavity } \\
\text { and pharynx }\end{array}$} & \multicolumn{2}{|c|}{ Larynx } \\
\hline & & Observed & Expected & Observed & Expected \\
\hline $\begin{array}{l}\text { Saracci et al }(18)^{\mathrm{a}} \\
\text { Olsen \& Jensen }(13)^{\mathrm{a}, \mathrm{b}} \\
\text { Saracci et al }(18)^{\mathrm{c}} \\
\text { Enterline \& Marsh }(6)^{\mathrm{c}} \\
\text { Enterline \& Marsh }(6)^{\mathrm{c}} \\
\text { Morgan }(9)^{\mathrm{c}} \\
\text { Morgan et al }(10)^{\mathrm{c}} \\
\text { Claude \& Frentzel-Beyme }(2)^{\mathrm{b}, \mathrm{c}} \\
\text { Bertrazzi et al }(1)^{\mathrm{b}, \mathrm{c}}\end{array}$ & $\begin{array}{r}121119 \\
49634 \\
248438 \\
341089 \\
41934 \\
47088 \\
33755 \\
19698\end{array}$ & $\begin{array}{r}14 \\
5 \\
6 \\
23 \\
3 \\
5 \\
3 \\
\cdots \\
\cdots\end{array}$ & $\begin{array}{c}12.08 \\
4.4 \\
6.60 \\
21.35 \\
2.96 \\
3.7 \\
2.61 \\
\cdots \\
\cdots\end{array}$ & $\begin{array}{r}4 \\
3 \\
7 \\
10 \\
- \\
2 \\
2 \\
2 \\
4\end{array}$ & $\begin{array}{l}5.05 \\
2.0 \\
4.18 \\
9.78 \\
1.37 \\
1.7 \\
1.2 \\
2 \\
0.98\end{array}$ \\
\hline
\end{tabular}

a Cancer incidence analysis.

b Included in Saracci's study (18).

c Mortality study. 
zi et al (1) reported a significant excess in laryngeal cancers; deaths due to this disease were significantly more frequent than expected in the group with the longest exposure and among the most heavily exposed workers. Three additional cases are presently known, and the authors are continuing the follow-up. Moreover, in the same country, Maggioni et al (7) recorded eight cases of laryngeal cancers. We believe that attention should be paid to the fact that similar findings originate from southern European countries, where cancers of the upper respiratory and alimentary tracts are frequent $(11,26)$.

The cancer in the locations observed by us are known to have a close relationship with alcohol and tobacco consumption $(11,15,16)$. As shown among current employees, tobacco consumption does not seem more frequent among the cohort than in the general population. Moreover, the fact that there was no increase in the incidence of lung cancers associated with tobacco consumption (3) (SIR 0.74) on the one hand and of esophageal cancers associated with alcohol consumption (24) (SIR 0.7) on the other suggests that these factors did not confound our results. Furthermore, the relationship between the incidence of cancers in the upper respiratory and alimentary tracts and the duration of exposure lets us suspect the etiologic role of glass fibers. Although the concentrations of respirable fibers were low in the factory studied, fibers probably entered the buccal cavity, pharynx, and larynx, regardless of their diameters or lengths. This probability rules out the notion of "respirable fibers." However, environmental fiber concentrations may have been higher in the past.

\section{Conclusions}

This study, conducted in France, points out an increased incidence of cancers of the pharynx, larynx, and buccal cavity associated with the duration of exposure to MMMF. This result is not apparently explained by an excess in alcohol or tobacco consumption. In the absence of similar findings, except from another southern European country (Italy), additional surveys are required to substantiate our results.

\section{Acknowledgments}

The authors would like to thank Dr L Simonato of the International Agency for Research on Cancer for his comments on the manuscript.

\section{References}

1. Bertazzi PA, Zocchetti C, Pesatori A, Radice L, Riboldi L. Mortalita per tumori in una coorte di produttori di fibre vetrose. Med Lav 75 (1984) 339-358.

2. Claude J, Frentzel-Beyme R. A mortality study of workers employed in a German rock wool factory. Scand $\mathrm{J}$ Work Environ Health 10 (1984) $151-157$.
3. Doll $\mathrm{R}$, Peto $\mathrm{R}$. Mortality in relation to smoking: 20 years' observations on male British doctors. Br Med J 2 (1976) $1525-1536$

4. Enterline PE, Henderson V. The health of retired fibrous glass workers. Arch Environ Health 30 (1975) 113-116.

5. Enterline PE, Marsh GM. The health of workers in the MMMF industry. In: Guthe T, ed. Biological effects of man-made mineral fibres. Proceedings of a WHO/IARC conference in association with JEMRB and TIMA, Copenhagen, 20-22 April 1982. Volume 1. World Health Organization, Copenhagen 1984, pp 311-339.

6. Enterline PE, Marsh GM, Esmen NA. Respiratory disease among workers exposed to man-made mineral fibers. Am Rev Respir Dis 128 (1983) $1-7$.

7. Maggioni A, Meregalli G, Sala C, Riva M. Patologia respiratoria e cutanea negli addetti alla produzione di fibre di vetro (filato). Med Lav 71 (1980) 216-227.

8. Menegoż F, Lutz JM. Le cancer dans l'Isère, 1979, 1980, 1981. Registre du cancer de l'Isère, Grenoble 1983.

9. Morgan RW. Mortality study of fibrous glass production workers. Arch Environ Health 36 (1981) 179-183.

10. Morgan RW, Kaplan SD, Bratsberg JA. Mortality in fibrous glass production workers. In: Guthe $T$, ed. Biological effects of man-made mineral fibres: Proceedings of a WHO/IARC conference in association with JEMRB and TIMA, Copenhagen 20-22 April 1982. Volume 1. World Health Organization, Copenhagen 1984, pp 340-346.

11. Moulin JJ, Mur JM, Cavelier C. Epidémiologie comparée, en Europe, des cancers liés au tabac (poumon, larynx, pharynx, cavité buccale). Bull Cancer 72 (1985) $155-158$.

12. Moulin JJ, Pham QT, Mur JM, Meyer-Bisch C, Massin N, Wild P, Teculescu D, Perreaux JP, Kauffer E, Delepine P, Caillard JF. Respiratory health of man-made mineral fibres production workers: Results of an epidemiological survey in France. In: Proceedings of the Sixth International Symposium on Inhaled Particles (Cambridge, 2-6 September 1985). Pergamon Press, Oxford (in press).

13. Olsen JG, Jensen OM. Cancer incidence among employees in one mineral wool production plant in Denmark. Scand J Work Environ Health 10 (1984) 17-24.

14. Robinson CF, Dement JM, Ness GO, Waxweiler RJ. Mortality patterns of rock and slag mineral wool production workers: An epidemiological and environmental study. Br J Ind Med 39 (1982) 45-53.

15. Rothman KJ, Cann CI, Flanders D, Fried MP. Epidemiology of laryngeal cancer. Epidemiol Rev 2 (1980) $195-209$.

16. Rothman KJ, Keller A. The effect of joint exposure to alcohol and tobacco on risk of cancer of the mouth and pharynx. J Chronic Dis 25 (1972) 711-716.

17. Saracci $R$, Simonato L. Man-made vitreous fibers and workers' health: An overview of the epidemiologic evidence. Scand J Work Environ Health 8 (1982) $234-242$.

18. Saracci $R$, Simonato L, Acheson ED, Andersen A, Bertazzi PA, Claude J, Charnay N, Estève J, FrentzelBeyme RR, Gardner MJ, Jensen OM, Maasing R, Olsen JH, Teppo LHI, Westerholm P, Zocchetti C. Mortality and incidence of cancer of workers in the man made vitreous fibres producing industry: An international investigation at 13 European plants. $\mathrm{Br} \mathrm{J}$ Ind Med 41 (1984) $425-436$.

19. Schaffer $\mathbf{P}$, Lavillaureix J. Le cancer dans le Bas-Rhin: Incidence des nouveaux cas de 1975 à 1977. Economica, Paris 1981.

20. Schraub S, Oppermann A. Registre des Tumeurs du Doubs, 1977-1981. Registre des Tumeurs du Doubs, Besançon 1983.

21. Shannon HS, Hayes M, Julian JA, Muir DCF. Mortality experience of glass fibre workers. Br J Ind Med 41 (1984) 
$35-38$.

22. Stanton MF, Layard M, Tegeris A, Miller E, May M, Kent E. Carcinogenicity of fibrous glass: Pleural response in the rat in relation to fiber dimension. J Natl Cancer Inst 58 (1977) 587-603.

23. Stanton MF, Wrench C. Mechanisms of mesothelioma induction with asbestos and fibrous glass. J Natl Cancer Inst 48 (1972) 797-817.

24. Tuyns AJ, Péquignot $G$, Jensen $O M$. Le cancer de l'oesophage en Ille-et-Vilaine en fonction des niveaux de consommation d'alcool et de tabac. Des risques qui se multiplient. Bull Cancer 64 (1977) 45-60.

25. Wagner JC, Berry GB, Hill RJ, Munday DE, Skidmore
JW. Effects of inhalation and intrapleural inoculation in rats. In: Guthe T, ed. Biological effects of man-made mineral fibres: Proceedings of a WHO/IARC conference, in association with JEMRB and TIMA, Copenhagen 20-22 April 1982. Volume II. World Health Organization, Copenhagen 1984, pp 209-233.

26. Waterhouse J, Muir C, Shanmugaratnam K, Powell J, ed. Cancer incidence in five continents. Volume IV. International Agency for Research on Cancer, Lyon 1982. (IARC scientific publications no 42 ).

Received for publication: 24 June 1985 